\title{
AKTIVITAS DAN SELEKTIVITAS KATALIS Mo-Co/USY PADA REAKSI HIDRODEOKSIGENASI ANISOL
}

\section{(ACTIVITY AND SELECTIVITY OF Mo-Co/USY CATALYST ON THE HYDRODEOXYGENATION (HDO) REACTION OF ANISOLE)}

\author{
Khoirina Dwi Nugrahaningtyas*, Yuniawan Hidayat, Prima Susan Prayekti \\ Fakultas Matematika dan Ilmu Pengetahuan Alam Universitas Sebelas Maret \\ J1. Ir. Sutami No 36 A Kentingan Surakarta \\ e-mail: khoirinadwi@mipa.uns.ac.id
}

\begin{abstract}
Abstrak
Penelitian ini bertujuan untuk mengetahui pengaruh katalis Mo-Co/USY terhadap distribusi dan konversi produk serta pengaruh penambahan logam Co terhadap selektivitas produk benzena pada reaksi hidrodeoksigenasi (HDO) anisol. Reaksi HDO anisol dilakukan dengan sistem alir. Produk yang terbentuk dianalisis dengan kromatografi gas-spektrometer massa GC-MS. Produk utama dari HDO anisol yaitu benzena dan toluene. Aktivitas katalis Mo$\mathrm{Co} / \mathrm{USY}$ lebih tinggi daripada USY dan termal. Katalis Mo-Co/USY B memiliki selektivitas tertinggi pada produk benzena (15\%).
\end{abstract}

Kata kunci: aktivitas katalis, hidrodeoksigenasi, katalis Mo-Co/USY, reaksi hidrodeoksigenasi anisol

\begin{abstract}
This research was conducted to study the effect of the catalyst Mo-Co/USY againts product distribution and product conversion, and the effect of addition Co metals towards selectivity-products benzene on the anisole HDO. The anisole HDO was prepared by flow reactor. The products were analyzed by GC-MS. The main products of the anisole HDO i.e benzene and toluene. The activity with Mo-Co/USY catalyst higher than USY and termal. Mo-Co/USY B catalyst has highest selectivity-products benzene (15\%).
\end{abstract}

Keywords: Catalyst activity, hydrodeoxygenation, hydrodeoxygenation reaction of anisole, Mo-Co/USY catalyst

\section{PENDAHULUAN}

Berbagai sumber energi banyak mengandung senyawa hidrokarbon. Salah satu sumber energi yaitu minyak bumi. Kandungan senyawa hidrokarbon dalam minyak bumi mencapai 50-98\%. Selain itu dalam minyak bumi juga terkandung unsurunsur seperti belerang, nitrogen dan oksigen. Senyawa-senyawa tersebut merupakan suatu pengotor di dalam minyak bumi. Oleh karena itu agar diperoleh kualitas produk bahan bakar yang baik serta mengurangi emisi polusi udara dari produk-produk bahan bakar yang dihasilkan perlu dilakukan suatu proses antara lain hidrotreating.

Hidrotreating merupakan proses perengkahan dengan mengalirkan gas hidrogen untuk menjenuhkan hidrokarbon serta 
Jurnal Penelitian Saintek, Vol. 20, Nomor 1, April 2015

menghilangkan pengotor sulfur, oksigen, antara katalis dengan molekul-molekul nitrogen serta logam yang berikatan pada hidrokarbon sebagai pengotor di dalam destilat minyak bumi. Salah satu proses hidrotreating adalah hidrodeoksigenasi (HDO). Hidrodeoksigenasi (HDO) bertujuan untuk menghilangkan senyawa kontaminan oksigen yang terikat pada senyawasenyawa hidrokarbon dengan menggunakan bantuan katalis dan gas hidrogen untuk mengkonversi senyawa menjadi produk sekaligus menghilangkan pengotor.

Selain katalis dan gas hidrogen, senyawa umpan juga penting untuk diperhatikan dalam reaksi HDO. Shah dan Cronauner (1979) menggunakan beberapa senyawa karbonil sebagai senyawa umpan untuk reaksi HDO. Dalam penelitian ini digunakan anisol sebagai senyawa umpan. Anisol memiliki atom $\mathrm{O}$ dari metoksi yang mewakili reaksi direct deoxygenation (DDO) dan cincin benzena yang bisa mewakili untuk reaksi hidrogenasi (HYD). HDO anisol didapatkan produk sikloheksana, sikloheksena, benzena, toluena, dan fenol (Viljava, 2001). Proses hidrodeoksigenasi ini tidak cukup hanya dengan perlakuan thermal saja, tetapi memerlukan bantuan katalis untuk mempercepat jalannya reaksi.

Pada reaksi hidrodeoksigenasi, fungsi katalis adalah menyediakan seluruh permukaan untuk mengadsorpsi molekulmolekul reaktan secara kimia sehingga terbentuk kompleks kimia tak stabil reaktan yang menyebabkan terjadi reaksi di antara reaktan-reaktan pada permukaan katalis (Gates, 1979). Hasil penelitian terdahulu menunjukan bahwa katalis $\mathrm{CoMo} / \mathrm{Al}_{2} \mathrm{O}_{3}$ sulfida mampu memberikan hasil terbaik dalam hal konversi dan laju deoksigenasi untuk reaksi hidrodeoksigenasi menggunakan senyawa model fenol, benzaldehida dan asetofenon (Wang et al, 2011).

Logam Co memiki daya adsorpsi dan desorpsi tidak terlalu kuat sehingga cocok untuk reaksi hidrogenasi (Annisa, 2012). Logam Mo akan lebih memegang peranan untuk reaksi deoksigenasi (Kubicka et al., 2010). Logam Mo bertindak sebagai sisi asam Brønsted yang dapat mengaktifkan C-O (Wang et al., 2011). Situs asam dari USY berfungsi sebagai situs aktif bagi reaksi-reaksi hidrogenasi dan dehidrogenasi sehingga gabungan antara logam dengan pengemban Ultra Stable Y-zeolite (USY) akan menghasilkan katalis yang bersifat multifungsional (Nugrahaningtyas, 2009). Logam Co pada katalis Mo-Co/USY divariasi karena semakin banyak kandungan Co semakin besar pula kemampuan untuk memecah hidrogen. Perbedaan penambahan konsentrasi logam Co, menyebabkan aktivitas dan selektivitas masing-masing katalis berbeda.

Karakter katalis Mo-Co/USY fresh dan bekas pada reaksi HDO anisol dapat 
dilihat dalam hal luas permukaan, volume pori dan rerata jari porinya. Hasil penelitian dari Utomo (2008) pada reaksi mengatakan bahwa terjadi penurunan luas permukaan dan volume pori pada katalis bekas sedangkan rerata jari pori pada katalis bekas naik. Hal ini disebabkan karena adanya pengotor pada katalis bekas. Perubahan luas permukaan, volume total pori dan rerata jari pori dapat juga disebabkan oleh penurunan aktivitas katalitik logamnya (Arifin, 2009). Mengacu pada pemaparan diatas telah dilakukan penelitian tentang reaksi HDO Anisol dengan menggunakan katalis Mo-Co/USY.

Penelitian ini bertujuan untuk mengetahui pengaruh katalis Mo-Co/USY terhadap distribusi dan konversi produk serta pengaruh penambahan logam Co terhadap selektivitas produk benzena pada reaksi hidrodeoksigenasi (HDO) anisol. Reaksi HDO anisol dilakukan dengan sistem alir.

\section{METODE PENELITIAN}

Uji katalis HDO dilakukan dengan memanggang katalis sebelum digunakan sekitar 1 jam. Katalis Mo-Co A sebanyak 0,5 g yang sudah dipanggang dimasukkan ke dalam kolom reaktor dengan susunan sebagai berikut: paling bawah, kasa digunakan sebagai penahan katalis, di atasnya diletakkan pelet katalis dan ditutup dengan kasa kembali. Selanjutnya reaktor dimasukkan ke dalam furnace. Alat yang akan digunakan disiapkan dan dicek kebocorannya dengan menggunakan gelembung sabun untuk memastikan tidak ada yang bocor. Kemudian kumparan pada alat dipanaskan terlebih dahulu. Setelah kumparan panas sekitar $100^{\circ} \mathrm{C}$ termo kontrol dinyalakan ditunggu sampai suhu reaktor sebesar $350{ }^{\circ} \mathrm{C}$ dan gas $\mathrm{H}_{2}$ dialirkan dengan laju alir $10 \mathrm{~mL} / \mathrm{menit}$. Anisol sebanyak $5 \mathrm{~mL}$ dimasukkan ke dalam labu leher tiga dan dihubungkan dengan kolom reaktor. Produk yang terbentuk dialirkan melalui kondensor yang telah dialiri dengan campuran air, es dan garam. Penampungan produk ditampung menggunakan venoject ditunggu hingga umpan pada labu leher tiga habis setelah itu proses dihentikan. Produk yang didapat dianalisa dengan GC-MS. Proses ini diulangi pada katalis yang lain.

\section{HASIL DAN PEMBAHASAN}

\section{Distribusi Produk}

Reaksi HDO anisol menggunakan katalis Mo-Co/USYdilakukan dengan menggunakan reaktor model alir. Umpan yang dilewatkan dalam reaktor dibawa oleh gas hidrogen dengan laju $5 \mathrm{~mL} / \mathrm{menit}$. Hasil reaksi HDO anisol ditampung menggunakan venoject. Hasil reaksi dianalisis menggunakan GC-MS pada fraksi cairnya. Hasil analisa distribusi produk dapat dilihat pada Tabel 1.

Tabel 1 menunjukkan bahwa produk yang terbentuk selain anisol dari termal didapatkan tiga produk, USY delapan 
Tabel 1. Distribusi Produk Total

\begin{tabular}{clcccccc}
\hline \multirow{2}{*}{ No } & \multirow{2}{*}{ Katalis } & \multicolumn{6}{c}{$\%$ Area } \\
\cline { 3 - 7 } & & Termal & USY & Mo-Co A & Mo-Co B & Mo-Co C & Mo-Co D \\
\hline 1 & Benzena & 0,38 & 0,27 & 0,73 & 0,77 & 0,34 & 0,23 \\
2 & Toluena & - & 0,48 & 0,62 & 0,19 & 0,41 & 0,24 \\
3 & Fenol & 1,94 & 6,75 & 2,95 & 2,89 & 4,31 & 3,03 \\
4 & Benzaldehid & 0,71 & - & - & 0,70 & - & - \\
5 & 2 metoksi toluena & - & - & 0,29 & - & - & - \\
6 & 3 metoksi toluena & - & 0,55 & - & - & 0.32 & - \\
7 & 4 metoksi toluena & - & 0,32 & 0,13 & - & - & - \\
8 & 2 metil fenol & - & 3,15 & 1,90 & - & 1,73 & 0,86 \\
9 & 4 metilbenzyl alkohol & - & 0,63 & - & 0,60 & 0,44 & - \\
10 & 2,3 dimetil Fenol & - & - & 0,47 & - & - & - \\
11 & Anisol & 96,97 & 87,85 & 92,91 & 94,85 & 92,45 & 95,64 \\
\hline
\end{tabular}

-: Tidak terdeteksi

produk, sedangkan dengan katalis Mo-Co A 7 produk, Mo-Co B 5 produk, Mo-Co C 6 produk dan Mo-Co D 4 produk. Distribusi produk ini dipengaruhi oleh kandungan logam Co. Pada termal didapatkan produk yang sedikit hal ini pada reaksi termal reaksinya tanpa katalis. Jika dilihat dari penambahan kandungan logam Co semakin banyak konsentrasi logam Co maka jenis produk yang diperoleh akan semakin sedikit. Hal ini dikarenakan logam Co memiliki orbital setengah penuh pada orbital d-nya, sifatnya sangat elektropositif menyebabkan Co bisa berikatan dengan $\mathrm{H}$-dari hidrogen yang elektronegatif. Logam Co juga bisa mengaktifkan gugus oksigen dan ikatan rangkap pada senyawa umpan. Selain itu Logam Co juga berperan dalam laju hidrogenasi (Romero, 2010).

\section{Aktivitas Katalis}

Produk Total

Hubungan jenis katalis dengan besarnya total HDO (\%) anisol disajikan pada Gambar 1.

Gambar 1 menggambarkan bahwa USY memiliki konversi total paling tinggi yaitu sebesar 8,38\% sedangkan yang terendah termal yaitu $2,48 \%$. Pada USY hal ini disebabkan karena USY memiliki luas permukaan paling tinggi yaitu $617,637 \mathrm{~m} 2 / \mathrm{g}$. Luas permukaan katalis akan mempengaruhi aktifitas katalis, semakin luas permukaan katalis maka fasa aktif yang tersebar semakin banyak sehingga aktivitasnya meningkat (Putera, 2008). Besarnya konversi total tidak dapat digunakan sebagai ukuran untuk menentukan baik tidaknya suatu katalis karena nilai konversi total besar belum tentu 


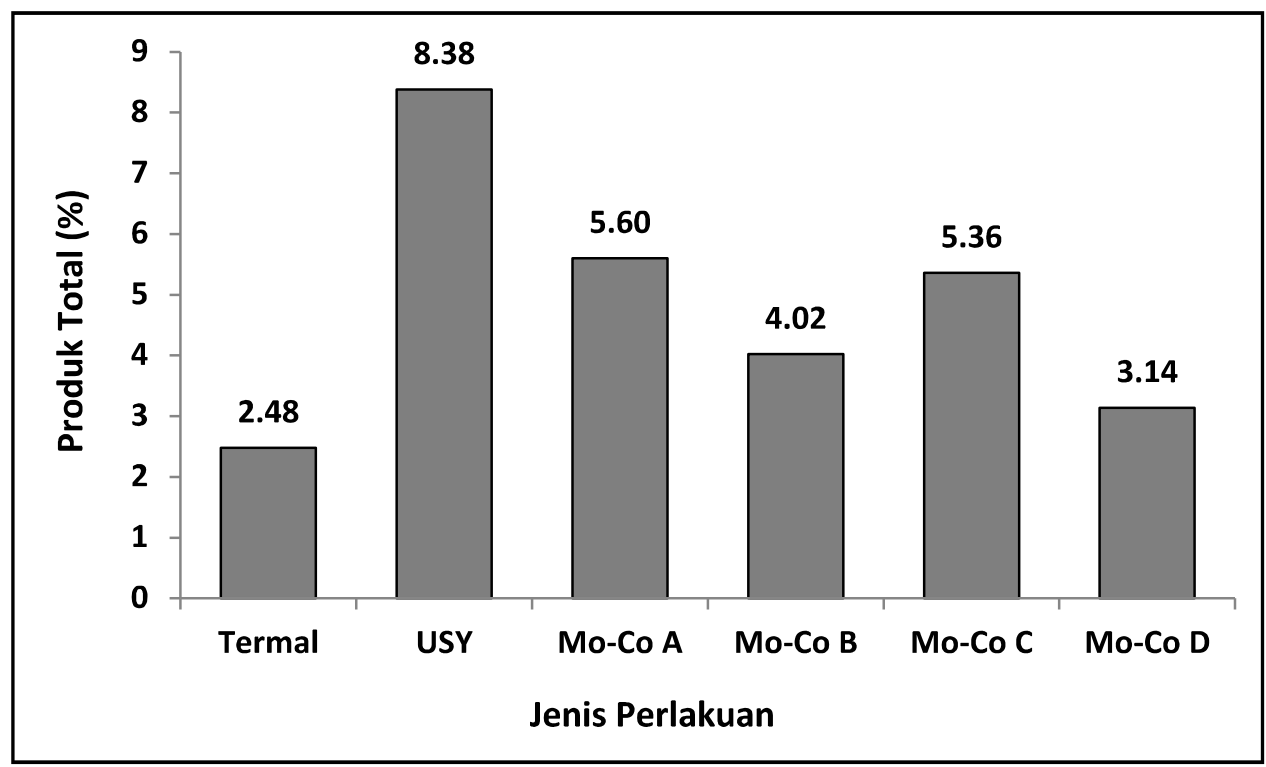

Gambar 1. Grafik Hubungan Jenis Perlakuan terhadap Produk Total

produk HDO yang didapatkan juga besar. Katalis dikatakan baik jika mendapatkan produk HDO lebih banyak.

\section{Aktivitas Katalitik HDO}

Aktivitas katalitik adalah kemampuan katalis dalammengkonversi anisol menjadi produk benzena dan toluene. Besarnya konversi anisol menjadi benzena dan toluene dihitung berdasarkan data GCMS dan menggunakan rumus seperti yang tersaji pada Bab III. Aktivitas katalitik HDO tersebut selanjutnya disebut persentase produk HDO. Hubungan besarnya persentase produk dengan jenis perlakuan yang berbeda disajikan pada Gambar 2.

Reaksi HDO anisol menggunakan katalis Mo-Co A diperoleh produk benzena lebih banyak yaitu sebesar $0,58 \%$ daripada dengan menggunakan termal (tanpa katalis) maupun dengan USY. Secara berurutan dari tertinggi ke rendah yaitu Mo-Co A $>$ termal $>$ USY. Sedangkan produk toluena juga lebih banyak sebesar 0,49\% daripada termal (tanpa katalis) maupun dengan USY. Hasil distribusi produk benzena untuk termal, USY dan Mo-Co A yang ditampilkan pada Gambar 2, tampak bahwa konversi benzena dan toluena meningkat secara signifikan saat menggunakan katalis Mo-Co A.

Hasil dari penelitian Mo-Co A mempunyai konversi benzena dan toluena paling besar dipengaruhi oleh adanya logam Co dan Mo yang diembankan pada USY akan membentuk produk lebih banyak. Hal ini disebabkan karena adanya asam Lewis dari logam Co dan asam Brønsted dari USY. Pada reaksi HDO ini terjadi dua mekanisme yang pertama yaitu dimetilasi dan transfer metal sesuai Viljava (2001) (Gambar 3). 


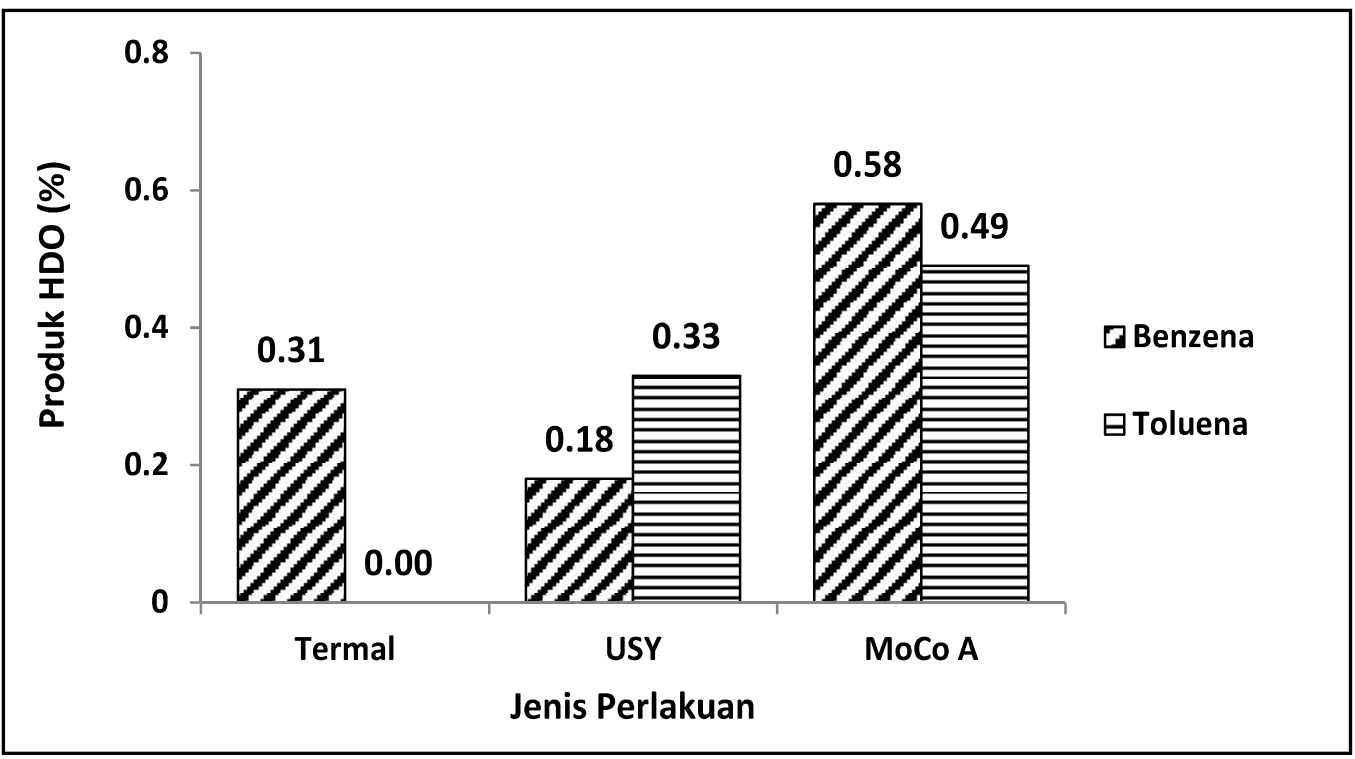

Gambar 2. Produk HDO Anisol

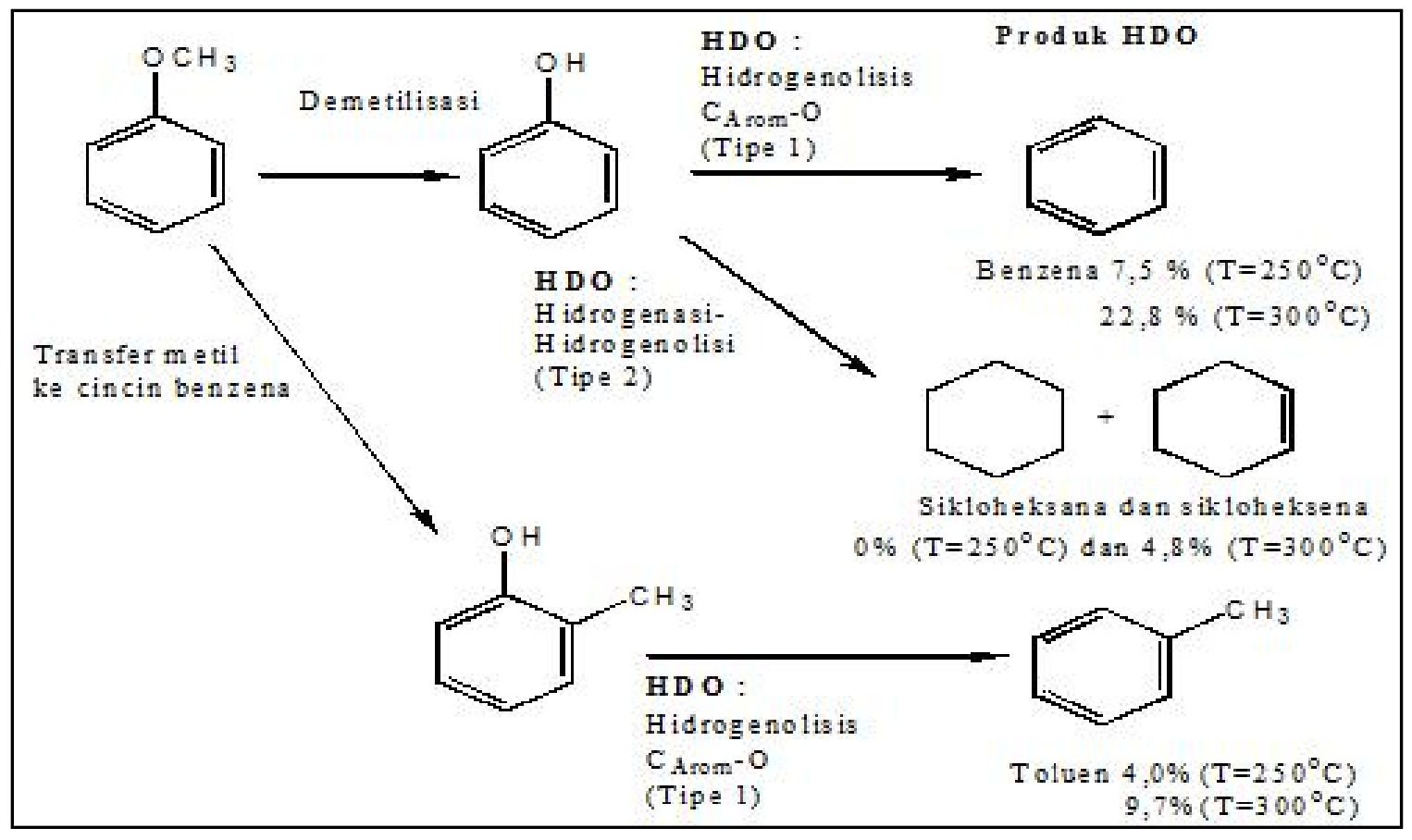

Gambar 3. Mekanisme Reaksi HDO Anisol pada Katalis $\mathrm{CoMo} / \gamma-\mathrm{Al}_{2} \mathrm{O}_{3}$ Terpresulfidasi (Viljava, 2001)

\section{Demetilasi}

Logam Co pada katalis Mo-Co A akan berfungsi untuk memecah $\mathrm{H}_{2}$. Dimana gas hidrogen akan berikatan dengan $\mathrm{CH}_{3}$ membentuk $\mathrm{CH}_{4}$, sedangkan yang lain akan mengikat logam Co. Kemudian $\mathrm{H}^{+}$dari asam Brønsted USY akan diikat oleh atom O dari anisol yang kehilangan $\mathrm{CH}_{3}$ membentuk fenol. Logam Mo juga akan mengikat gugus hidroksi dari fenol sehingga terjadi proses 
hidrogenolisis. Dari proses hidrogenolis tersebut terjadi pelepasan $\mathrm{H}_{2} \mathrm{O}$ dan terbentuk produk benzena.

Transfer metil

Pada katalis Mo-Co A, anisol mempunyai gugus metoksi $\left(\mathrm{O}-\mathrm{CH}_{3}\right)$, atom $\mathrm{O}$ sangat elektronegatif dan $\mathrm{CH}_{3}$ elektro positif. Karena atom $\mathrm{O}$ menarik elektron dari $\mathrm{CH}_{3}$ sehingga $\mathrm{CH}_{3}$ lepas. Asam Brønsted yaitu $\mathrm{H}^{+}$pada USY akan diserang oleh ikatan rangkap dari anisol. Ikatan rangkap pada anisol menjadi ikatan tunggal sehingga terjadi transfer metil. Asam Lewis akan mengikat $\mathrm{H}$ dan logam Co mengikat $\mathrm{H}$ dari hidrogen. Atom $\mathrm{O}$ mengikat asam Brønsted sehingga dihasilkan produk toluol. Logam Mo akan mengikat gugus hidroksi dari toluol sehingga terjadi proses hidrogenolisis. Dari proses hidrogenolis tersebut terbentuk produk toluena.

Pada USY juga bisa terbentuk produk benzena dan toluena hal ini dikarenakan adanya asam Brønsted dan asam lewis pada USY. Asam Brønsted memiliki H+ yang bisa diserang oleh atom oksigen dan ikatan rangkap dari anisol. Asam lewis yang mempunyai atom oksigen bisa mengikat $\mathrm{H}$ dari gas hidrogen. Sehingga perlakuan dengan menggunakan USY saja juga mampu membentuk produk HDO. Namun hasil yang didapat tidak sebanyak menggunakan katalis Mo-Co A. Sehingga dapat disimpulkan bahwa katalis Mo-Co
A memiliki aktivitas katalitik yang lebih tinggi untuk menghasilkan produk HDO yaitu benzena dan toluena dibanding USY maupun termal (tanpa katalis).

\section{Produk HDO Variasi Penambahan Logam Co} Hubungan besarnya produk HDO (\%) dengan variasi penambahan logam Co akan disajikan pada Gambar 4.

Pada Gambar 4, aktivitas katalis yang paling baik untuk membentuk produk benzena yaitu pada katalis Mo-Co B sebesar $0,6 \%$. Jadi urutan aktivitas katalis terbaik dalam mengkonversi benzena yaitu MoCo $\mathrm{B}>\mathrm{Mo}-\mathrm{Co} \mathrm{A}>\mathrm{Mo-Co} \mathrm{C}>\mathrm{Mo-Co} \mathrm{D}$. Sedangkan hasil toluena terbesar yaitu pada Mo-Co A sebesar 0,49\%. Dimana urutan aktivitas katalis dalam mengkonversi produk toluena yaitu Mo-Co $\mathrm{A}>\mathrm{Mo}-\mathrm{Co}$ D>Mo-Co C>Mo-Co B. Hasil tersebut tidak sesuai dengan asumsi karakter katalis pada jumlah kandungan logam yang teremban. Namun hasil ini sesuai dengan penelitian Wang (2010), dimana semakin banyak penambahan logam Co mengakibatkan terjadi penumpukan logam Co. Karena terjadi penumpukan logam Co tersebut akan mengakibatkan situs aktifnya tertutupi. Hal ini mengakibatkan aktivitas katalisnya menjadi menurun.

\section{Produk antara}

Selain produk HDO terbentuk juga produk antara, dimana Gambar 5 akan 


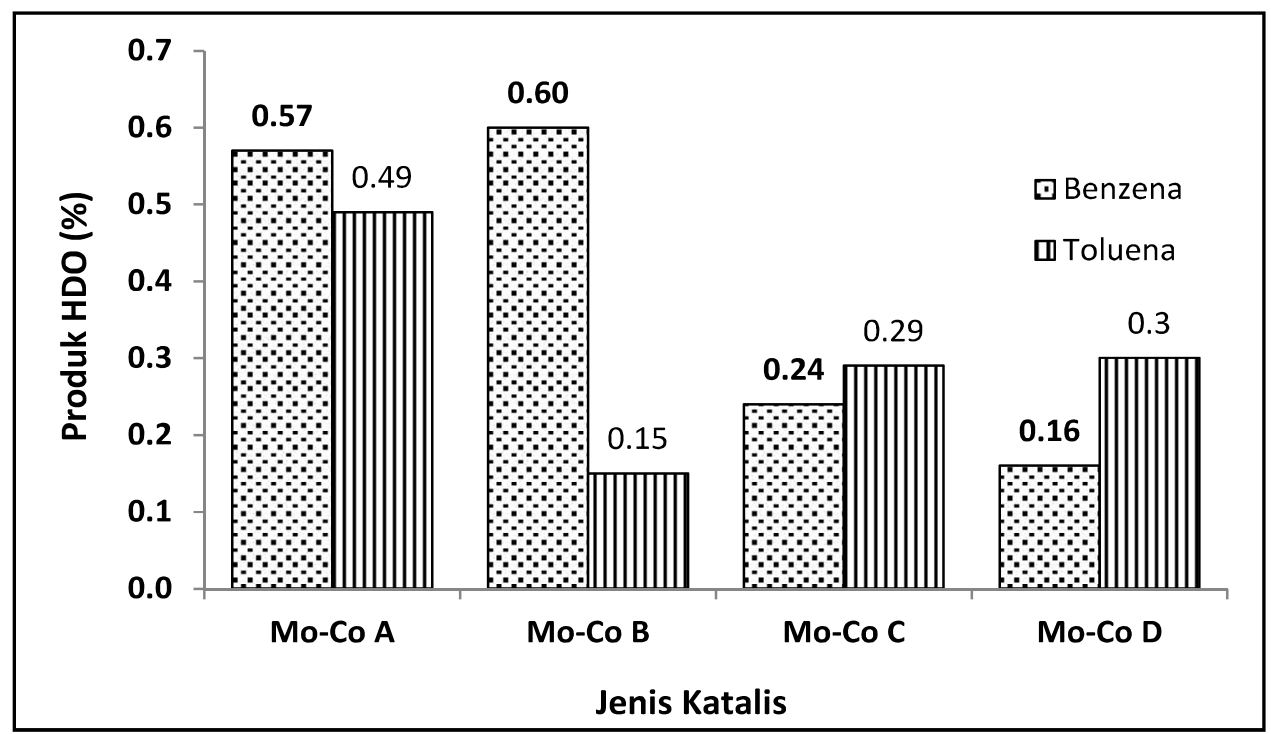

Gambar 4. Pengaruh Variasi Penambahan Logam Co terhadap Produk HDO

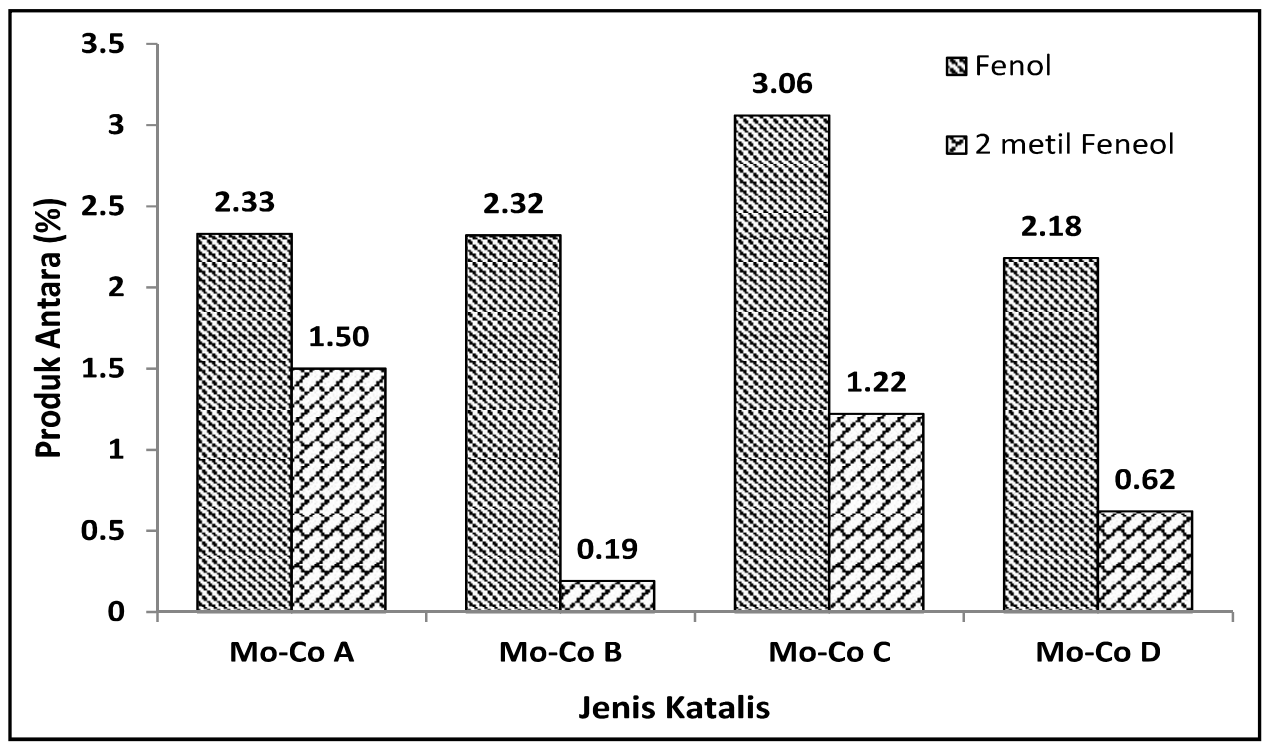

Gambar 5. Produk Antara

disajikan hubungan besarnya produk antara (\%) dengan penambahan logam Co. Aktivitas katalitik terbaik untuk menghasilkan fenol ditunjukkan pada Gambar 5, yaitu pada katalis Mo-Co C sebesar 3,06\%. Aktivitas katalitik terbaik untuk produk antara urutannya yaitu Mo-Co C>Mo-Co A>Mo-Co B>Mo-Co D. Produk antara fenol paling tinggi namun tidak berbanding lurus dengan produk benzena yang didapatkan. Kemungkinan yang terjadi disebabkan adanya reaksi dimetilasi yang kemudian tidak dapat mengalami reaksi lebih lanjut yaitu terhidrogenolisis untuk menghasilkan produk HDO. Jika dilihat berdasarkan data produk antara yang dihasilkan, tidak sesuai dengan jumlah kandungan logam Co yang ditambahkan. 
Produk antara dua metil fenol pada katalis Mo-Co A sebesar 1,5\%. Hal ini terjadi karena adanya reaksi transfer metil. Jika dilihat dari kandungan logam produk antara yang dihasilkan tidak sesuai dengan jumlah kandungan logam Co yang teremban. Seharusnya semakin banyak logam Co produk antara semakin kecil. Produk antara yang didapat lebih banyak dari pada produk HDO. Hal ini dikarenakan logam Co yang berada diluar memiliki reaksi hidrogenasi yang tinggi, karena terjadi penumpukan logam Co menyebabkan situs aktif logam Mo tertutupi sehingga reaksi deoksigenasi semakin kecil (Wang et al, 2011).

\section{Selektivitas Produk Benzena}

Katalis Mo-Co B memiliki selektivitas yang paling besar untuk medapatkan produk benzena yaitu sebesar 15\% (Gambar 6).
Hal ini berbanding lurus dengan aktivitas katalis dimana aktivitas katalis yang semakin meningkat maka semakin selektif katalis tersebut. Namun hal ini tidak sesuai dengan asumsi dari kandungan logam yang diembankan. Berdasarkan penelitian yang dilakukan oleh Wang (2010) hal ini disebabkan karena jumlah kandungan logam Co yang teremban terlalu padat. Logam Co yang terlalu padat tersebut membentuk agregat yang menutupi situs aktif USY sehingga mencapai hasil yang optimal pada katalis Mo-Co B. Kandungan logam yang terlalu padat tersebut disebabkan karena adanya penumpukan logam sehingga situs aktif logam tertutupi. Jika situs aktifnya banyak yang tertutupi maka semakin sedikit situs aktif yang ada di permukaan sehingga menyebabkan selektivitasnya menurun.

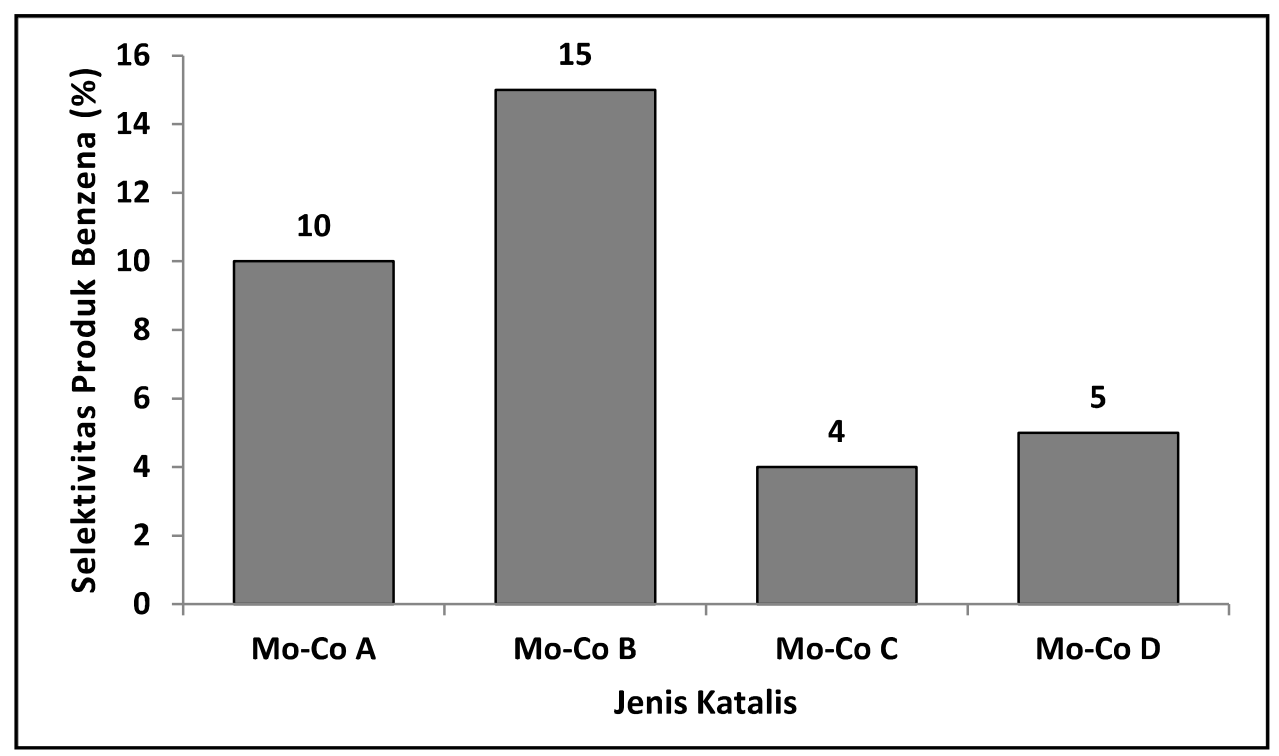

Gambar 6. Selektivitas Katalis terhadap Produk Benzena 
Jurnal Penelitian Saintek, Vol. 20, Nomor 1, April 2015

\section{KESIMPULAN}

Adanya katalis Mo-Co/USY dapat meningkatkan aktivitas produk HDO yaitu benzena $0,58 \%$ dan toluene 0,49 $\%$ daripada USY dan termal. Selektivitas produk benzena tertinggi yaitu katalis MoCo B sebesar $15 \%$.

\section{DAFTAR PUSTAKA}

Annisa, G. 2012. Hidrodeoksigenasi Bio-Oil Menggunakan Katalis CoMo/C untuk Optimasi Produksi Alkana dan Alkohol. Skripsi. Universitas Indonesia.

Arifin, S. 2009. Uji katalis $\mathrm{Pt} / \mathrm{\gamma}-\mathrm{Al}_{2} \mathrm{O}_{3}$ untuk reaksi HDO THF. Skripsi. FMIPA Universitas Sebelas Maret.

Gates, R.P.H. 1979. An Introduction to Chemisorpsi and Catalyst by Metals. Oxford: Clarendon Press.

Kubicka, D., Ludek, K. 2010. Deoxygenation of Vegetable Oils over Sulfided Ni, Mo and NiMo Catalysts. Applied Catalysis A: General, hlm. 199-208.

Nugrahaningtyas, K.D., Trisunaryanti W., Triyono, Nuryono, Widjonarko, D.M., Yusnani, A., dan Mulyani. 2009. Preparasi dan Karakterisasi Katalis Logam Tak Tersulfidasi: Ni/USY dan NiMo/USY, Indonesian Journal of Chemistry, vol 9, hlm. 177-183.

Putera, S. 2008. Adsorpsi Logam Nikel dan Analisis Kristalinitas H-Faujasit dari Abu Layang Batubara, FMIPA, Universitas Lambung Mangkurat.

Romero, Y., Richard, F., dan Brunet, S. 2010. Hydrodeoxygenation of 2-Ethylphenol as a Model Compound of Bio-crude over Sulfided Mo Based Catalysts: Promoting Effect and Reaction Mechanism. Applied Catalysis B: Environmental, Vol 98, hlm. 213-223.

Shah, Y.T., and Cronauner, D.C. 1979. Oxygen, Nitrogen, and Sulfur Removal Reaction in Donor Solvent Coal Liquifaction. Catalyst Review, Vol 2, hlm. 209-301.

Utomo, M.P. 2008. Deaktivasi Katalis pada Konversi Pentanol Menjadi Pentana dengan Katalis Pt/Zeolit. Proseding Seminar Nasional Kimia, FMIPA Universitas Negeri Yogyakarta.

Viljava, T.R. 2001. From Biomass to Fuels: Hydrotreating of Oxygen Containing Feeds on $\mathrm{A} \mathrm{CoMo} /-\mathrm{Al}_{2} \mathrm{O}_{3} \mathrm{HDS}$ Catalyst. Catalyst Today, Vol 60, hlm. 11-48.

Wang, W., Yunquan, Y., Hean, L., Tao, H., Wenying, L. 2010. Characterization and Hydrodeoxygenation Propertiesof Co Promoted Ni-Mo-B Amorphous Catalysts: Influence of Co Content. Catalyst Communication, Vol 101, hlm. 105-115.

Wang, W., Yunquan, Y., Hean, L., Tao, H., Wenying, L. 2011. Preparation and Hydrodeoxygenation Properties of CoMo-O-B Amorphous Catalyst. Catalyst Communication, Vol 12, hlm. 436-420. 